\title{
KARAKTERISTIK HUNIAN PERMUKIMAN KUMUH KAMPUNG SAPIRIA KELURAHAN LEMBO KOTA MAKASSAR
}

\author{
Andi Annisa Amalia*1 \\ Program Studi Arsitektur, Universitas Muhammadiyah Makassar \\ e-mail:*1 annisa@unismuh.ac.id
}

\begin{abstract}
Abstrak_ Pemenuhan kebutuhan tempat tinggal bagi kaum migran yang seringkali menyewa rumah di bagian pusat kota karena dekat dengan lokasi mata pencaharian berdampak pada terjadinya proses perkembangan bangunan yang tidak terkendali dan menciptakan permukiman kumuh. Kampung Sapiria merupakan salah satu permukiman di Kota Makassar yang didominasi oleh kaum migran. Hal ini karena nilai strategis lokasinya pada tepian air Bantaran Kanal Pannampu ,dekat dengan simpul-simpul jasa distribusi kota, terdapat fasilitas pendidikan, dan kemudahan akses menuju Pelabuhan Paotere serta Tol Reformasi. Kampung Sapiria yang terletak di Kelurahan Lembo merupakan salah satu dari 103 titik kumuh di Kota Makassar dengan luas kumuh 4,53 ha. Lokasi kumuh Kampung Sapiria Kelurahan Lembo berada di RW 002 dan RW 005 berkategori kumuh sedang. Penelitian ini bertujuan mengidentifikasi karakteristik kumuh Kampung Sapiria dari aspek bangunan hunian meliputi ketidakteraturan bangunan, kepadatan bangunan hunian, ketidaksesuaian dengan persyaratan teknis bangunan, dan legalitas bangunan. Metode penelitian yang digunakan adalah kuantitatif deskriptif. Hasil identifikasi karakteristik hunian permukiman kumuh Kampung Sapiria diketahui bahwa 28 \% bangunan yang memiliki ketidakteraturan, $85 \%$ bangunan hunian yang memiliki luas lantai tidak sesuai standar, $22 \%$ bangunan hunian tidak sesuai persyaratan teknis, $10 \%$ bangunan hunian memiliki IMB dan $5 \%$ dengan status lahan milik.
\end{abstract}

Kata kunci : Migran ; Kekumuhan ; Ketidakteraturan ; Kepadatan ; Legalitas.

\begin{abstract}
Fulfilling residential needs for migrants who often rent houses in the downtown area as close to livelihood locations has an impact on uncontrolled development of buildings and creating slums. Kampung Sapiria is one of the settlements in Makassar City which is dominated by migrants. This is because of the strategic value of its location on the waterfront of Pannampu Canal, close to the nodes of the city's distribution services, educational facilities, and easy access to Paotere Port and Reform Toll. Kampung Sapiria located in Lembo Village is one of 103 slum point in Makassar City with slum area of $4.53 \mathrm{ha}$. The slum location of Kampung Sapiria Kelurahan Lembo is located at RW 002 and RW 005 is categorized as slum. This study aims to identify the slum characteristics of Kampung Sapiria from the aspects of residential buildings including building irregularity, density of residential buildings, nonconformities with the technical requirements of the building, and the legality of the building. The research method used is quantitative descriptive. The result of identification of residential characteristics of Kampung Sapiria slums is known that $28 \%$ of buildings have irregularities, $85 \%$ of residential buildings with non-standard floor area, $22 \%$ of residential buildings are not in accordance with technical requirements, 10\% of residential buildings have IMB and $5 \%$ property.
\end{abstract}

Keywords : Migrants; The slums; Irregularities; Density; Legality.

\footnotetext{
${ }^{1}$ Program Studi Arsitektur, Universitas Muhammadiyah Makassar
} 


\section{PENDAHULUAN}

Pesatnya perkembangan permukiman perkotaan disebabkan oleh pertumbuhan penduduk maupun urbanisasi yang mengakibatkan timbulnya permukiman kumuh (Solehati, Irwansyah, Caisarina. 2017). Hal ini memicu peningkatan pelayananan dasar perkotaan terhadap kebutuhan hunian. Perumahan dan permukiman menjadi permasalahan di kawasan perkotaan, tidak hanya terkait dengan penyediaan lahan dan harga lahan, tetapi juga permasalahan mewujudkan hunian yang layak bagi masyarakat. Permasalahan tersebut timbul pada saat tingginya pertumbuhan penduduk perkotaan yang berakibat pada meningkatnya tuntutan akan kebutuhan perumahan, selain itu pemerintah juga tidak memiliki kemampuan finansial yang memadai untuk memenuhi tingginya tuntutan ketersediaan hunian, cadangan lahan yang tersisa di bagian dalam kawasan perkotaan dengan keterbatasan kemampuan dan keterampilan. kaum migran tersebut tidak dapat tertampung pada sektor formal yang dapat meningkatkan kualitas hidup, mereka terpaksa hidup di sektor informal dalam skala kecil dan penghasilan rendah.

Dalam upaya pemenuhan kebutuhan tempat tinggal, kaum migran seringkali menyewa rumah di bagian pusat kota yang dekat dengan lokasi mata pencaharian. Akibatnya, terjadi proses pemadatan bangunan yang tidak terkendali dan menciptakan permukiman kumuhatau slums (Priyatno, 2016). Sebagian yang lain membuat bangunan sendiri dan material seadanya pada bagian-bagian tertentu yang dianggap tidak ada status hukum atas tanah sehingga berdampak pada munculnya permukiman liar (squatter settlement). Kumuh sampai saat ini dianggap sebagai fenomena kondisi 'current living space being' yang diterjemahkan sebagai korban pasif pembangunan sehingga harus dipisahkan dalam sistem hidup keruangan.

Menurut Undang-Undang No. 1 Tahun 2011 tentang Perumahan dan Kawasan Permukiman, Permukiman kumuh adalah permukiman yang tidak layak huni karena ketidakteraturan bangunan, tingkat kepadatan bangunan yang tinggi, dan kualitas bangunan serta sarana dan prasarana yang tidak memenuhi syarat. Luas kumuh Kota Makassar pada tahun 2014 adalah 740, 10 Ha yang tersebar di 103 titik kelurahan berdasarkan SK Walikota Makassar tentang Penetapan Kawasan Kumuh No: 050.05/1341/Kep/IV/2014 yang terdiri dari36kelurahan kategori kumuh berat, 51kelurahan kategori kumuh sedang dan 17kelurahan kategori kumuh ringan. Hingga akhir tahun 2017 berbagai kebijakan dan program penanganan yang dilakukan pemerintah Kota berkolaborasi dengan pemerintah pusat, swasta dan stakeholder terkait lainnya. Karakteristik kawasan kumuh di Kota Makassar ditandai dengan bangunan hunian yang illegal dan tidak teratur, adanya fasilitas umum dan prasana lingkungan permukiman yang belum memadai dan tidak direncanakan secara detail untuk pertumbuhan kawasan permukiman, tidak terpenuhinya kebutuhan air bersih terutama daerah pesisir, jaringan drainase lingkungan yang tidak terkoneksi dengan badan air, dan sistem pengelolaan dan ketersediaan sarana dan prasarana persampahan yang tidak memadai.

Berdasarkan kajian terhadap Dokumen SIAP (Slum Improvement Action Plan) Kota Makassar tahun 2017, tiga aspek kumuh dominan di Kota Makassar adalah 45,36 \% sistem sarana dan prasarana persampahan belum terolah, 41,09\% kondisi drainase lingkungan tidak sesuai standar teknis serta 40,08 \% kondisi bangunan hunian belum memenuhi standar kelayakan . Ketiga aspek rata-rata berada pada tipologi kumuh dataran rendah, pusat kota, bantaran kanal, tepi sungai, kumuh sempadan pantai bahkan terdapat bangunan kumuh di atas sungai.

Penelitian ini dilakukan pada lokasi kumuh dengan kategori sedang di Kampung Sapiria Kelurahan Lembo karena pemukim didominasi kaum migran, merupakan area yang dilalui Kanal 
Pannampu, dekat dengan simpul-simpul jasa distribusi kota,terdapat fasilitas pendidikan, serta kemudahan akses menuju Pelabuhan Paotere dan Tol Reformasi. Penelitian ini bertujuan mengidentifikasi karakteristik kumuh Kampung Sapiria dari aspek bangunan hunian meliputi ketidakteraturan bangunan, kepadatan bangunan hunian, ketidaksesuaian dengan persyaratan teknis bangunan, dan legalitas bangunan di kawasan permukiman kumuh.

\section{METODE}

Penelitian ini mengidentifikasi karakteristik permukiman kumuh yang menggunakan metode kuantitatif deskriptif dengan mengacu pada kriteria kekumuhan berdasarkan Peraturan Menteri Pekerjaan Umum Nomor 02 Tahun 2016 tentang Peningkatan Kualitas terhadap Perumahan dan Permukiman Kumuh. Penelitian dilaksanakan selama 2 bulan mulai dari Bulan Oktober-Desember Tahun 2017 di Kampung Sapiria Kelurahan Lembo. Lokasi penelitian tepatnya di kawasan kumuh RW 02 yang terdiri dari RT 01, RT 02, RT 03 RT 04 serta RW 05 yang terdiri dari RT 01, RT 02, RT 03, RT 04, RT 05 dan RT 06.

Tabel 1. Kriteria dan Parameter Karakteristik Bangunan Hunian

\begin{tabular}{|c|c|c|}
\hline No & Kriteria & Parameter \\
\hline 1 & Ketidakteraturan Bangunan Hunian & $\begin{array}{l}\text { Posisi muka bangunan hunian tidak } \\
\text { menghadap ke jalan } \\
\text { - Menghadap langsung atau berada di atas } \\
\text { sempadan } \\
\text { sungai/kanal/laut/rawa/danau } \\
\text { - Berada di daerah buangan limbah } \\
\text { pabrik/di bawah jalur tegangan tinggi } \\
\text { (sutet) }\end{array}$ \\
\hline 2 & Kepadatan Bangunan Hunian & Luas lantai bangunan $<7,2 \mathrm{~m}^{2} /$ jiwa \\
\hline 3 & $\begin{array}{l}\text { Ketidaksesuaian dengan persyaratan teknis } \\
\text { bangunan }\end{array}$ & $\begin{array}{l}\text { Atap terluas bocor, dinding rusak, lantai } \\
\text { terluas berupa tanah }\end{array}$ \\
\hline 4 & Legalitas bangunan & $\begin{array}{l}\text { - Bangunan hunian yang memiliki IMB } \\
\text { - Bangunan hunian yang memiliki } \\
\text { SHM/HGB/surat yang diakui pemerintah }\end{array}$ \\
\hline
\end{tabular}

Sumber: Peraturan Menteri Pekerjaan Umum dan Perumahan Rakyat Nomor 02/PRT/M/2016 Tentang Peningkatan Kualitas Terhadap Perumahan Kumuh dan Permukiman Kumuh.

Dalam merumuskan persentase bangunan hunian untuk masing masing kriteria dapat dilihat pada tabel berikut.

Tabel 2. Rumus Persentase Bangunan Hunian Berdasarkan Kriteria

\begin{tabular}{|c|c|c|}
\hline No & Kriteria & Rumus \\
\hline 1 & $\begin{array}{c}\text { Persentase } \\
\text { ketidakteraturan } \\
\text { bangunan hunian }\end{array}$ & $\left(\frac{\text { Jumlah Bangunan hunian tidak teratur }}{\text { Jumlah Total Bangunan hunian }} \times 100\right)$ \\
\hline 2 & $\begin{array}{l}\text { Persentase Kepadatan } \\
\text { Bangunan Hunian }\end{array}$ & $\left(\frac{\text { Jumlah hunian dengan luas lantai } \geq 7,2 \mathrm{~m} 2 / \text { orang }}{\text { Jumlah Total Bangunan hunian }} \times 100\right)$ \\
\hline
\end{tabular}




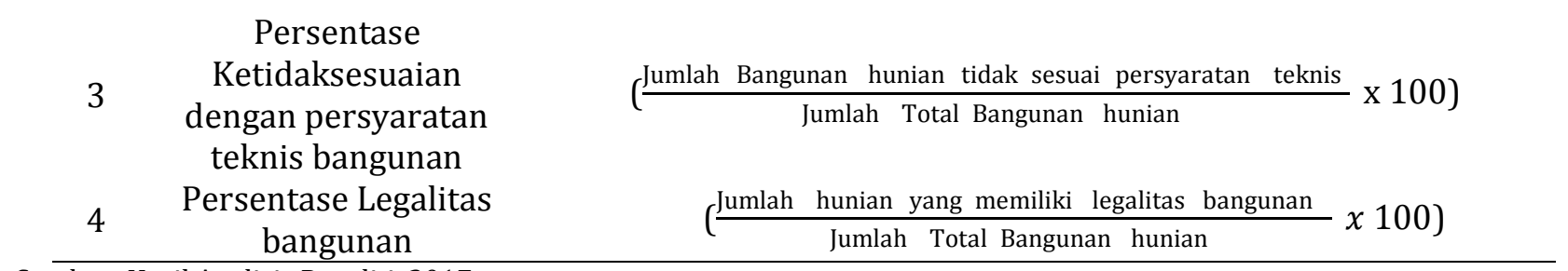

Sumber: Hasil Analisis Peneliti, 2017

\section{HASIL DAN PEMBAHASAN}

\section{A. Gambaran Umum Kampung Sapiria}

Secara historis, penamaan Kelurahan Lembo berasal dari nama orang yang dituakan di kawasan tersebut pada masa lampau yaitu Puang Lembo, yang awalnya didominasi oleh Suku Bugis Makassar. Seiring dengan perkembangan Kota Makassar, kini Kelurahan Lembo mengalami pergeseran komposisi penduduk yang didominasi kaum migran dan sudah menetap (bermukim) di Kelurahan Lembo. Kawasan kumuh Kelurahan Lembo terletak di Kampung Sapiria yang penamaannya berasal dari Bahasa Makassar yaitu Sapiri yang artinya kemiri. Dulu Kampung Sapiri ditumbuhi banyak ditumbuhi vegetasi yang didominasi oleh Pohon Kemiri yang tumbuh subur di sekitar Tempat Pekuburan Beroanging. Sapiri inilah yang hingga saat ini lebih dikenal dengan Sapiria.

Kelurahan Lembo dengan luas 56,29 Ha, terdapat 33,09 Ha kawasan permukiman yang tersebar di 5 RW dan 32 RT. Secara spasial luas kawasan kumuh Lembo terletak di Kampung Sapiria dengan luas 4,53 $\mathrm{Ha}$ atau $13 \%$ dari total luas permukiman. Secara administrasi Kampung sapiria yang terletak di RW 02 dan RW 05 Kelurahan Lembo berbatasan sebelah utara dengan RW 01 Kelurahan Lembo, sebelah timur dengan RW 03 Kelurahan Lembo, sebelah selatan dengan RW 04 Kelurahan Lembo, sebelah barat berbatasan dengan Kanal Pannampu dan Kelurahan Bunga Eja Beru.

Kampung Sapiria memiliki topografi relatif datar berada pada ketinggian 1-8 $\mathrm{m}$ di atas permukaan laut dengan tingkat kemiringan lereng berada pada kemiringan 0-2 \% (Kota Makassar dalam Angka 2017) . Sedangkan kondisi geologi berupa batuan endapan alluvium dan pantai. Untuk kondisi hidorologi di Kampung Sapiria, merujuk pada kondisi hidrologi Kota Makassar yang dipengaruhi oleh satu kanal besar yaitu Kanal Pannampu yang bermuara di sebelah barat kelurahan. Kanal Pannampu bermuara hingga ke Sungai Tallo yang berada di sebelah utara Kota Makassar. Debit Sungai Tallo berkisar antara 238,8-1.152 $\mathrm{m}^{3} /$ detik dengan debit rata-rata tahunan sebesar 33,05 m³/detik (Revisi RTRW Makassar, 2015).

Berdasarkan Profil Baseline 100-0-100 Kelurahan Lembo Tahun 2017, jumlah penduduk Kampung Sapiria tercatat 3.097 Jiwa yang terdiri dari 1.563 jiwa Laki-Laki dan 1.534 jiwa perempuan. Luas wilayah Kampung Sapiria 8,45 Ha dengan tingkat kepadatan penduduk 366,50 jiwa/ ha atau termasuk kategori kepadatan tinggi.Secara umum, fungsi penggunaan lahan di Kampung Sapiria Kelurahan Lembo dibedakan atas fungsi permukiman dan mixed-use yang terdiri dari sekolah, permukiman, masjid, kanal, dan rawa-rawa.

\section{B. Fenomena Kumuh Kampung Sapiria}

Kondisi permukiman kumuh Kampung Sapiria Kelurahan Lembo dipengaruhi oleh migrasi. Perkembangan Kota Makassar yang pesat, menjadi faktor penarik bagi kaum migran yang umumnya mempunyai kondisi ekonomi rendah (MBR). Kampung Sapiria yang berada di 
sekitar area pekuburan di Kelurahan Lembo menjadi piihan mereka untuk bermukim karena lokasinya dekat dengan simpul-simpul jasa distribusi kota, dimana masyarakat mencari penghidupan. Akibat desakan kebutuhan hunian dan pelayanan fasilitas infrastruktur dasar permukiman yang terbatas menjadikan kondisi permukiman di Kampung Sapiria menjadi kumuh.

\begin{tabular}{cccccc} 
Tabel 3. Sebaran Kumuh Kawasan & Jumlah \\
No & $\begin{array}{c}\text { Nama RT/Lokasi } \\
\text { Kumuh }\end{array}$ & $\begin{array}{c}\text { Luas } \\
\text { Kumuh } \\
\text { (Ha) }\end{array}$ & $\begin{array}{c}\text { Kenduduk di } \\
\text { lokasi kumuh } \\
\text { (Jiwa) }\end{array}$ & $\begin{array}{c}\text { Kepadatan Penduduk } \\
\text { di Lokasi Kumuh } \\
\text { (Jiwa/Ha) }\end{array}$ & $\begin{array}{c}\text { Kepadatan } \\
\text { Bangunan di Lokasi } \\
\text { Kumuh }\end{array}$ \\
\hline 1 & RT 001 RW 002 & 0.62 & 281 & 453 & 116 \\
2 & RT 002 RW 002 & 0.32 & 274 & 856 & 166 \\
3 & RT 003 RW 002 & 0.39 & 457 & 1.172 & 200 \\
4 & RT 004 RW 002 & 0.27 & 219 & 811 & 193 \\
5 & RT 001 RW 005 & 0.62 & 222 & 358 & 144 \\
6 & RT 002 RW 005 & 0.32 & 267 & 834 & 116 \\
7 & RT 003 RW 005 & 0.45 & 254 & 564 & 144 \\
8 & RT 004 RW 005 & 0.34 & 293 & 862 & 119 \\
9 & RT 005 RW 005 & 0.78 & 488 & 626 & $\mathbf{1 3 7 . 8}$
\end{tabular}

Sumber: Hasil Analisis Peneliti, 2017

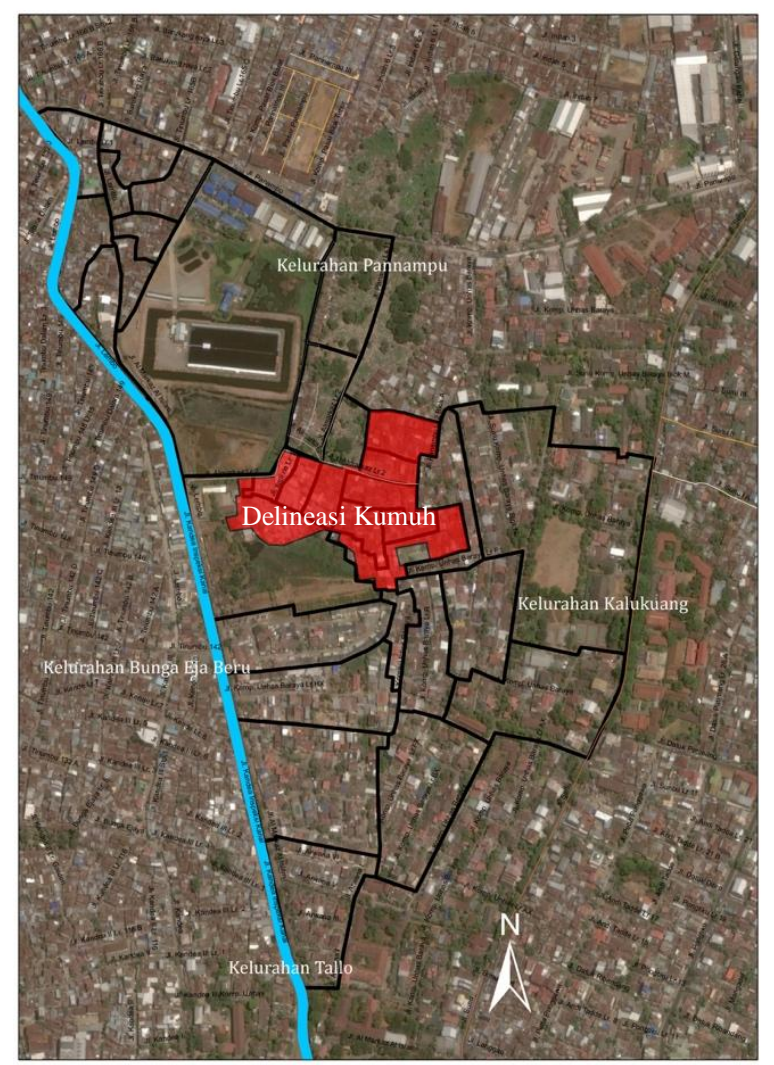

Gambar 1 : Delineasi kumuh Kampung Sapiria Kelurahan Lembo Sumber: Survey Lapangan, 2017 

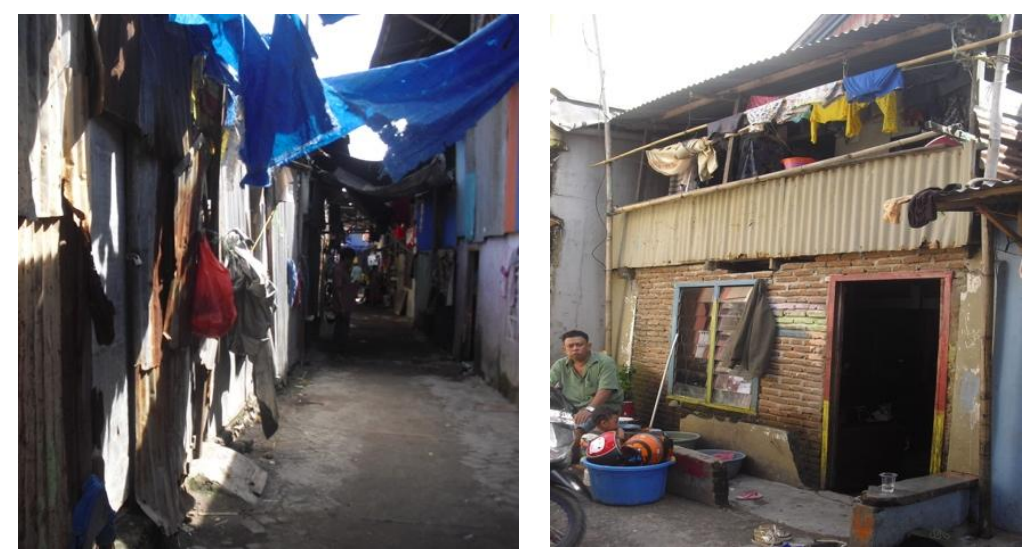

Gambar 2 : Potret kekumuhan Kampung Sapiria Kelurahan Lembo Sumber: Dokumentasi Peneliti, 2017

\section{Hasil Identifikasi Karakteristik Bangunan Hunian}

Kondisi bangunan hunian Permukiman kumuh Kampung Sapiria mencakup tiga kriteria yaitu ketidakteraturan bangunan hunian, tingkat kepadatan bangunan dan ketidaksesuaian dengan persyaratan teknis bangunan.

\section{Ketidakteraturan Bangunan Hunian}

Ketidakteraturan bangunan hunian yang ada di kawasan kumuh Kampung Sapiria ratarata karena orientasi rumah menghadap ke jalan yang lebarnya $\leq 1,5$ meter, dan muka bangunan ada yang tidak menghadap langsung ke jalan.

Tabel 4. Ketidakteraturan Bangunan Hunian Kampung Sapiria

\begin{tabular}{ccccc}
\hline No Nama RT/Lokasi Kumuh & $\begin{array}{c}\text { Jumlah Total } \\
\text { Bangunan } \\
\text { Hunian (Unit) }\end{array}$ & $\begin{array}{c}\text { Jumlah } \\
\text { Bangunan } \\
\text { Hunian Tidak } \\
\text { Teratur } \\
\text { (Unit) }\end{array}$ & $\begin{array}{c}\text { Persentase Bangunan Hunian } \\
\text { Tidak Teratur (\%) }\end{array}$ \\
\hline 1 & RT 001 RW 002 & 72 & 12 & 17 \\
2 & RT 002 RW 002 & 53 & 19 & 36 \\
3 & RT 003 RW 002 & 78 & 29 & 50 \\
4 & RT 004 RW 002 & 52 & 26 & 0 \\
5 & RT 001 RW 005 & 56 & 0 & 9 \\
6 & RT 002 RW 005 & 46 & 4 & 24 \\
7 & RT 003 RW 005 & 52 & 17 & 41 \\
8 & RT 004 RW 005 & 49 & 12 & 30 \\
9 & RT 005 RW 005 & 70 & 29 & $\mathbf{2 8}$ \\
\hline
\end{tabular}

Sumber: Hasil Analisis Peneliti, 2017 


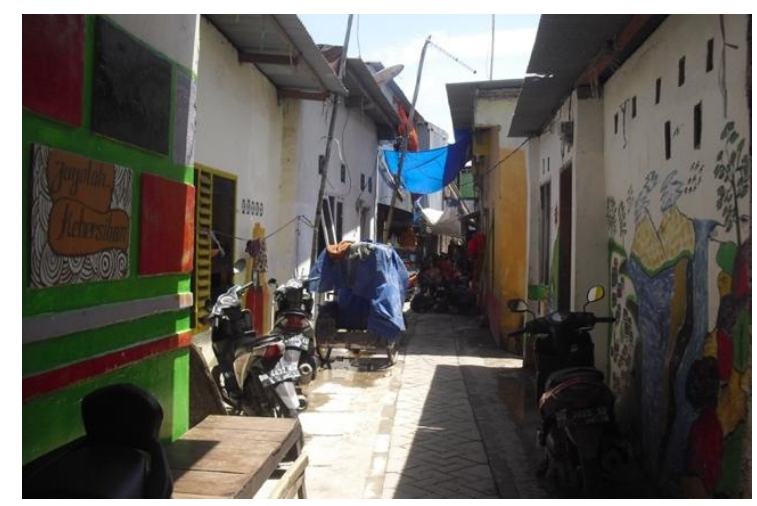

Gambar 3 : Bangunan tidak teratur di Kampung Sapiria Kelurahan Lembo Sumber: Dokumentasi Peneliti, 2017

\section{Kepadatan Bangunan Hunian}

Dari total 578 unit bangunan di Kampung Sapiria yang tidak teratur, 76 diantaranya belum memenuhi standar luasan. Hal ini dikarenakan rata-rata dihuni lebih dari 2-3 KK dalam satu rumah tangga.

Tabel 5. Hunian dengan Luas Lantai Sesuai Standar

\begin{tabular}{ccccc}
\hline No & $\begin{array}{c}\text { Nama RT/Lokasi } \\
\text { Kumuh }\end{array}$ & $\begin{array}{c}\text { Jumlah Total } \\
\text { Bangunan } \\
\text { Hunian (Unit) }\end{array}$ & $\begin{array}{c}\text { Jumlah Hunian } \\
\text { memiliki Luas } \\
\text { Lantai } \geq 7,2 \\
\text { m²/orang }^{2}\end{array}$ & $\begin{array}{c}\text { Persentase Bangunan Hunian } \\
\text { memiliki Luas Lantai } \geq 7,2 \text { m² }^{2} \text { orang } \\
(\%)\end{array}$ \\
\hline 1 & RT 001 RW 002 & 72 & 17 & 24 \\
2 & RT 002 RW 002 & 53 & 6 & 11 \\
3 & RT 003 RW 002 & 78 & 12 & 15 \\
4 & RT 004 RW 002 & 52 & 5 & 10 \\
5 & RT 001 RW 005 & 56 & 1 & 2 \\
6 & RT 002 RW 005 & 46 & 1 & 13 \\
7 & RT 003 RW 005 & 52 & 7 & 12 \\
8 & RT 004 RW 005 & 49 & 6 & 29 \\
9 & RT 005 RW 005 & 70 & 20 & $\mathbf{1 5}$ \\
\hline
\end{tabular}

Sumber: Hasil Analisis Peneliti, 2017

Berdasarkan tabulasi di atas dapat disimpulkan bahwa hanya $15 \%$ bangunan hunian di Kampung Sapiria yang memenuhi standar luasan, sedangkan 85 \% diantaranya masih dibawah standar. Ukuran rumah variatif, namun tidak sesuai dengan jumlah penghuni yang ada di dalamnya. Sebagai contoh, terdapat hunian berukuran $5 \times 8$ meter dengan jumlah anggota keluarga hingga 10 jiwa atau 2 KK didalamnya.

\section{Ketidaksesuaian dengan Persyaratan Teknis Bangunan}

Berdasarkan penelitian di lapangan terdapat bangunan yang permanen dan semi permanen. Bangunan permanen didominasi oleh material batu bata dan beton campuran, sedangkan bangunan semi permanen didominasi material kayu, papan dan tripleks bekas. Bangunan semi permanen ini secara visual tidak layak huni karena tidak ada sirkulasi antar 
hunian dan jalan lingkungannya, material sudah mulai rusak baik pada dinding, atap yang bocor, bahkan lantai masih ada yang berupa lantai semen.

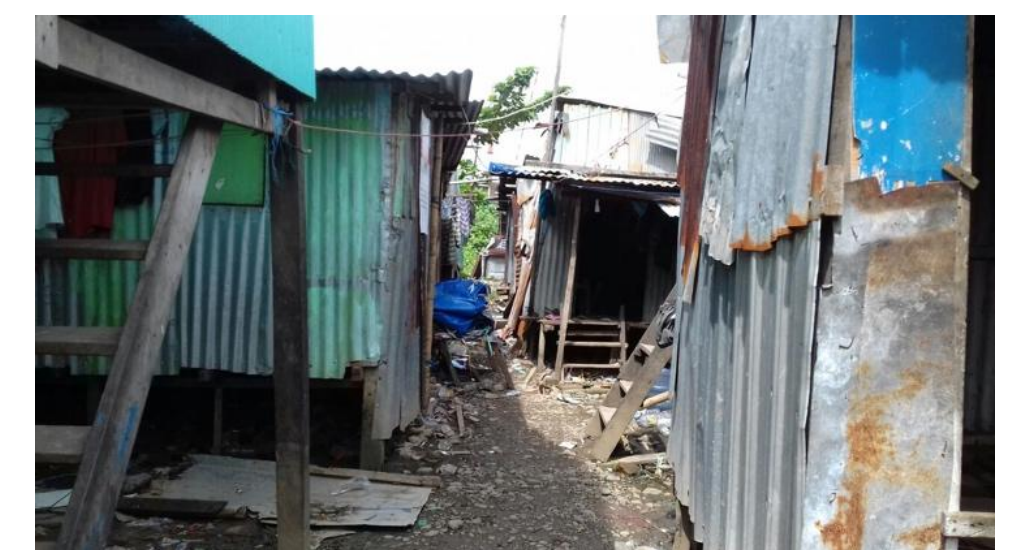

Gambar 4 : Bangunan Hunian Tidak Layak Huni diKampung Sapiria Sumber: Dokumentasi Peneliti , 2017

Tabel 6. Ketidaksesuaian dengan Persyaratan Teknis Bangunan Kampung Sapiria

\begin{tabular}{ccccc}
\hline No & $\begin{array}{c}\text { Nama RT/Lokasi } \\
\text { Kumuh }\end{array}$ & $\begin{array}{c}\text { Jumlah Total } \\
\text { Bangunan } \\
\text { Hunian }\end{array}$ & $\begin{array}{c}\text { Jumlah Bangunan } \\
\text { Hunian Memiliki } \\
\text { Kondisi Atap, Lantai, } \\
\text { Dinding tidak Sesuai } \\
\text { Persyaratan Teknis } \\
\text { (Rumah Tangga) }\end{array}$ & $\begin{array}{c}\text { Persentase Bangunan Hunian } \\
\text { Memiliki Kondisi Atap, Lantai, } \\
\text { Dinding tidak Sesuai Persyaratan } \\
\text { Teknis } \\
(\%)\end{array}$ \\
\hline 1 & RT 001 RW 002 & 72 & 0 & 0 \\
2 & RT 002 RW 002 & 53 & 0 & 0 \\
3 & RT 003 RW 002 & 78 & 25 & 32 \\
4 & RT 004 RW 002 & 52 & 3 & 6 \\
5 & RT 001 RW 005 & 56 & 3 & 7 \\
6 & RT 002 RW 005 & 46 & 3 & 38 \\
7 & RT 003 RW 005 & 52 & 20 & 27 \\
8 & RT 004 RW 005 & 49 & 13 & 70 \\
9 & RT 005 RW 005 & 70 & 25 & $\mathbf{2 2}$ \\
\hline
\end{tabular}

Sumber: Hasil Analisis Peneliti, 2017

\section{Legalitas Bangunan}

Legalitas bangunan menggunakan parameter kepemilikan Surat Ijin Mendirikan Bangunan (IMB), sedangkan kepemilikan lahan menggunakan parameter SHM/HGB atau surat yang diakui pemerintah. Bangunan hunian di permukiman kumuh Kampung Sapiria yang memiliki IMB dapat dilihat pada tabel 7 berikut. 
Tabel 7. Bangunan Hunian yang Memiliki IMB

\begin{tabular}{ccccc}
\hline No & $\begin{array}{c}\text { Nama RT/Lokasi } \\
\text { Kumuh }\end{array}$ & $\begin{array}{c}\text { Jumlah Total } \\
\text { Bangunan } \\
\text { Hunian }\end{array}$ & $\begin{array}{c}\text { Jumlah Bangunan } \\
\text { Hunian memiliki } \\
\text { IMB (Rumah } \\
\text { Tangga) }\end{array}$ & $\begin{array}{c}\text { Persentase Bangunan } \\
\text { Hunian } \\
\text { memiliki IMB } \\
(\%)\end{array}$ \\
\hline 1 & RT 001 RW 002 & 72 & 0 & 0 \\
2 & RT 002 RW 002 & 53 & 0 & 0 \\
3 & RT 003 RW 002 & 78 & 0 & 0 \\
4 & RT 004 RW 002 & 52 & 0 & 0 \\
5 & RT 001 RW 005 & 56 & 0 & 0 \\
6 & RT 002 RW 005 & 46 & 0 & 0 \\
7 & RT 003 RW 005 & 52 & 0 & 0 \\
8 & RT 004 RW 005 & 49 & 0 & 21 \\
9 & RT 005 RW 005 & 70 & 15 & 80 \\
& RT 006 RW 005 & 50 & 40 & $\mathbf{1 0}$ \\
\hline
\end{tabular}

Sumber: Hasil Analisis Peneliti, 2017

Berdasarkan Tabel 7 di atas dapat disimpulkan bahwa terdapat $90 \%$ bangunan hunian tidak memiliki IMB (Ijin Mendirikan Bangunan). Hal ini disebabkan karena masih minimnya pengetahuan masyarakat terkait aturan pendirian banguna. Selain karena mereka adalah MBR (Masyarakat berpenghasilan Rendah), rata-rata juga beranggapan bahwa tidak perlu mengurus IMB bila renovasinya tidak permanen karena hanya melakukan pengecatan, penambahan ruang di dalam rumah, atau mengganti material yang rusak.

Tabel 8. Kondisi Kepemilikan Lahan Kampung Sapiria

No
Jumlah Total Bangunan Hunian
Jumlah Bangunan

Hunian memiliki SHM/HGB/Surat yang

Diakui Pemerintah

(Rumah Tangga)
Persentase

Bangunan Hunian memiliki SHM/HGB/Surat yang Diakui

Pemerintah (Rumah Tangga) $(\%)$

\begin{tabular}{ccccc}
\hline 1 & RT 001 RW 002 & 72 & 0 & 0 \\
2 & RT 002 RW 002 & 53 & 0 & 0 \\
3 & RT 003 RW 002 & 78 & 0 & 0 \\
4 & RT 004 RW 002 & 52 & 0 & 0 \\
5 & RT 001 RW 005 & 56 & 0 & 0 \\
6 & RT 002 RW 005 & 46 & 0 & 0 \\
7 & RT 003 RW 005 & 52 & 0 & 0 \\
8 & RT 004 RW 005 & 49 & 0 & 24 \\
9 & RT 005 RW 005 & 70 & 17 & $\mathbf{5}$ \\
\hline
\end{tabular}

Sumber: Hasil Analisis Peneliti, 2017

Berdasarkan Tabel 8 diatas dapat disimpulkan bahwa $95 \%$ dari jumlah bangunan hunian di Kampung Sapiria belum memiliki SHM (Sertifikat Hak Milik) atau Hak Guna Bangunan. Sehingga dapat dikatakan masih illegal, walaupun rata-rata mereka tetap 
membayar PBB (Pajak Bumi dan Bangunan). Hal ini disebabkan karena penghuni didominasi oleh kaum migran yang tinggal untuk bekerja dan pendidikan yang hanya kontrak/sewa atau menumpang. Sedangkan penghuni tetap di Kampung Sapiria sebagian besar memiliki rumah karena warisan.

\section{KESIMPULAN}

Berdasarkan hasil penelitian yang dilakukan terhadap karakteristik bangunan hunian Kampung Sapiria Kelurahan Lembo diketahui bahwa $28 \%$ bangunan yang memiliki ketidakteraturan, $85 \%$ bangunan hunian yang memiliki luas lantai tidak sesuai standar, $22 \%$ bangunan hunian tidak sesuai persyaratan teknis, $10 \%$ bangunan hunian memiliki IMB dan $5 \%$ dengan status lahan milik. Untuk itu, Pemerintah Kota Makassar perlu melakukan percepatan penanganan permukiman kumuh berbasis perspektif kondisi kekumuhan sebagai future well becoming atau target berkelanjutanserta mampumencegahtumbuhnya kumuh baru.

\section{DAFTAR REFERENSI}

Nursyahbani, Pigawati. "Kajian Karakteristik Permukiman Kumuh di Kampung Kota, Studi Kasus Kampung Gandekan Semarang." Teknik PWK :4, No.2 (2015): 270-269.

Solehati, Irwansyah, Caisarina. "Identifikasi Karakteristik Permukiman Kumuh Gampong Telaga Tujuh, Kota Langsa, Aceh." Special Issue : 1, No. 2 (2017):358-349.

Priyatno, Budi. (2014). Skema Inovatif Penanganan Permukiman Kumuh.Yogyakarta : Gadjah Mada University Press.

Undang-Undang Nomor 1 Tahun 2011 Tentang “Perumahan dan Kawasan Permukiman”. (2011). Jakarta.

Peraturan Menteri Pekerjaan Umum dan Perumahan Rakyat Nomor 02/PRT/M/2016 Tentang "Peningkatan Kualitas Terhadap Perumahan Kumuh dan Permukiman Kumuh" Tahun 2016. (2016). Jakarta.

SK Walikota Makassar tentang. "Penetapan Kawasan Kumuh" No: 050.05/1341/Kep/IV/2014 Tahun 2014. Makassar.

Kota Makassar dalam Angka 2017. (2017). Makassar : Badan Pusat Statistik Kota Makassar.

Revisi Rencana Tata Ruang Wilayah (RTRW) Kota Makassar Tahun 2015-2034. (2015). Makassar : Badan Perencanaan Pembangunan Daerah Kota Makassar.

Dokumen Slum Improvement Action Plan (SIAP) Kota Makassar. (2017). Makassar :Badan Perencanaan Pembangunan Daerah Kota Makassar.

Profil Baseline 100-0-100 Kelurahan Lembo Kota Makassar. (2017). Makassar: Program Kotaku Direktorat Jenderal Cipta Karya Kementrian Pekerjaan Umum dan Perumahan Rakyat.

Gusmaini. (2010). Identifikasi Karakteristik Permukiman Kumuh. Skripsi. Institut Pertanian Bogor. 